Journal of Teacher Education for Sustainability, vol. 19, no. 1, pp. 106-116, 2017

\title{
Analysis of the Demand for Distance Education at Eastern and Central European Higher Education Institutions
}

\author{
Daina Vasilevska \\ Liepaja University, Latvia \\ Baiba Rivza \\ Latvia University of Agriculture, Latvia \\ Tatjana Pivac \\ University of Novi Sad, Serbia \\ Vilija Alekneviciene \\ Aleksandras Stulginskis University, Lithuania \\ Agnieszka Parlińska \\ Warsaw University of Life Sciences, Poland
}

\begin{abstract}
Distance education as one of the new and perspective forms of completing higher education increases in popularity around the world. At the same time, the development of this model of education generates new problems: organization of the study process and information security. Distance learning allows solving a problem of accessibility of higher education in case of social issues, working hours, etc. Therefore, distance education is of major importance in increasing the learning efficiency.

The Latvian model of distance education is passing the stage of formation and approbation in the market of educational services. However, the creation of system of distance education should not be the final step for higher education institutions as such; furthermore, this process would not be developed without students. Therefore, the objective of the present research is to find out the opinion of the students on the expediency of distance education. More than 850 students from Poland, Lithuania, Latvia, Serbia and Belarus have participated in the research.

Results of the research have revealed that the traditional form of education based on communication between the lecturer and the student is more demanded among the students. At present, distance learning, unfortunately, cannot be characterised by stable demand. In order to increase the demand for such model of education, public presentations and discussions should be made, and media support is also necessary.
\end{abstract}

Keywords: advantages, disadvantages, distance learning, accessibility, higher education. 


\section{Introduction}

Onrush of technology in various fields of human activity requires the fast supply of knowledge as well as creates the demand for knowledge. Timely retargeting and expertise at work also promote the specialists to more actively acquire new skills. In many countries, the education institutions model the teaching and learning process, taking into account the market requirements and employers' demand. Graduate of a higher education institution is not only required to be an expert in the professional field, but also to have strong technological skills. Distance education provides such knowledge and skills at the moment of enrolment or offers acquiring them within a short period of time. Therefore, distance education enables one to develop skills necessary for the information search process, thereby improving general intelligence and critical thinking skills.

The two main factors have led to an explosion of interest in distance learning: the growing need for continual skills upgrading and retraining; and the technological advances that have made it possible to teach more and more subjects at a distance (UNESCO, 2002).

In many countries, education institutions introduce amendments and innovations to the study process with the help of new technologies. The features to be mentioned are pedagogical, administrative, informational, organisational, technical and other. Undoubtedly, working experience in the distance education system in various countries influences the development of worldwide web of distance education (Perraton, 2007; Khan \& Ally, 2015).

Nowadays, most European universities offer distance education. On this market, universities offer educational services with unique educational models, courses and programmes for distance education. Departments of the universities develop new technologies and approaches to the implementation of distance education.

The Latvian model of distance education undergoes the process of formation and evolvement in the market of educational services. Subsequently, numerous questions arise: Are students prepared for learning under conditions of distance education model? Is the distance education model able to accommodate the requests of students for education? How demanded is this education model at higher education institutions of other countries?

\section{Methodology}

For the purpose of the present research, it is necessary to clarify the level of student satisfaction of distance education management and organization, to identify the strengths and weaknesses of this education model in Latvia, as well as to compare it with similar models at higher education institutions in Lithuania, Serbia, Poland and Belarus.

In accordance with the aim of the research, the following tasks are set: to create new students' survey, to carry out the survey of target audience, to identify the factors that determine demand for the distance education model.

The research was conducted from September 2014 to August 2015 at higher education institutions in Latvia, Lithuania, Serbia, Poland and Belarus. The choice of the institutions was based on their experience in organising distance education with the help of current information and communication technologies. The survey was carried out among intramural and extramural (distance) students. The two groups were distinguished: 1) students with experience of the distance education model (59\% of respondents), 
2 ) students with experience of the traditional study model (41\% of respondents). The representative quota sampling (the total number of respondents) was 877 (491 females and 386 males).

The students' survey aims at identifying the demand for the distance learning study model, recognising its problems and development trends. The questionnaire included 24 items: 18 questions about distance learning, attitude towards distance learning, and about computer skills; 2 questions about demographics, and 4 questions about the education institution. Data have been processed using the statistical software SPSS for Windows 16 and Excel.

\section{Results}

In the scholarly literature it is stated that the distance education model can be differentiated from the traditional one based on the following criteria: flexibility, economic efficiency, performance and non-reliance of students (Garrison, 2000; Holmberg, 2008). Taking into account these criteria as differentials, the aim of the research is to examine the demand for distance education among students. The choice of the preferred model of education is very individual. In order to make the right choice, each person needs to know the characteristics (i.e., specific features, benefits and drawbacks) of the market of educational services that provides different knowledge acquisition forms. The lack of information or its misinterpretation frequently leads to a lapse in judgment. Survey data have revealed that $92 \%$ of respondents are familiar with the distance education model, but only $54 \%$ are certain about all its characteristics. In turn, $8 \%$ of full-time students have no idea about this model.

Dividing the acquired percentage into groups according to the satisfaction with the choice of educational model, it has been revealed that the percentage of those who have chosen the traditional model and are satisfied with it is $67.4 \%$. On the contrary, $32.6 \%$ would prefer studying at the distance education study program or at least studying part of subjects at a distance. It indicates the necessity to improve the traditional education model by applying contemporary teaching and learning methods, as well as using information technology. Out of the students enrolled in distance education study programs, only $42 \%$ are completely satisfied and $32 \%$ would prefer the traditional form of education, while $26 \%$ respondents have pointed out that this education model is not suitable for them. When using the distance education model, the adequate level of content and quality is not achieved. As a result, the consumers choose it with expectations that are probably not supposed to be fulfilled in the distance model. However, the model still has its requirements and controls for its execution. Seemingly, the advantages of distance education model described in the literature are often not demanded and lead to dissatisfaction of consumers.

The distance education model is based on the frequent use of current information and communication technologies. Initially, it indicates the ability to effectively use computer, to use all contemporary information and telecommunication means that are the basis for a two-way communication between the student and the lecturer. Therefore, the student not only needs to have basic computer skills and web browsing skills, but also needs to have experience working with the authentic information and finding it in various Internet sources. To be able to undertake distance learning, students should know good learning techniques (scanning, skimming, working with online handbooks 
and dictionaries), so distance learning requires not only knowledge, but also relevant skills.

During the survey, it has been determined that $96 \%$ of respondents have a personal computer. As one can see, this indicator is already high enough. As to the Internet usage rate, the situation slightly differs. Out of the total number of respondents, only $12 \%$ prefer Internet resources in the learning process at higher education institutions and $11 \%$ of respondents prefer individual learning, using video lectures or educational movies (Fig. 3).

Evaluating their computer skills, $4 \%$ of students have stated that they have only basic computer skills. Nevertheless, more objectivity has been found from screening the answers to the question about the command of information technologies.

Afterwards, four levels of skills have been distinguished. The first level includes basic knowledge of the operating system (Windows, Linux), use of several basic programs, such as word processors, calculator, and games. The second level includes knowledge of basic and office programs, ability to work with word processors, create graphs, charts, diagrams, table reports, and presentations. The third level includes knowledge of not only operating systems, but also of basic and office programs, as well as professional programs (for bookkeepers - 1C, for secretaries - data bases, for web-designers CMS, for advertising specialists - specific graphic editors such as CorelDraw). The fourth level requires specific knowledge - ability to work with operating systems at the level of systems administrator (ECDL, 2014). As a result, it has been established that the number of respondents with low command of various programs is notably larger than according to self-assessment. Around $10 \%$ of the respondents have good command of only one program. Majority of the respondents (53\%) are ordinary users, i.e., use only basic and office programs (Table 1). Students from Serbia evaluated their computer skills more critically; none of them rated themselves as being "Proficient".

Table 1

Level of Computer Skills (\% of the respondent number in the group)

\begin{tabular}{lcccc}
\hline \multicolumn{1}{c}{ Country } & Proficient & Advanced & Intermediate & Basic \\
\hline Latvia & 14 & 30 & 48 & 8 \\
\hline Lithuania & 8 & 31 & 47 & 14 \\
\hline Poland & 4 & 34 & 64 & 9 \\
\hline Serbia & 0 & 25 & 62 & 13 \\
\hline Belarus & 10 & 40 & 44 & 6 \\
\hline
\end{tabular}

As it is known, apart from a vast number of computer programs, the distance education model provides extensive use of such forms of communication as video conferences, seminars, progress tutorials in the elaboration process of papers, essays or degree theses, as well as various video materials and slide lectures.

However, despite the attractiveness of distance education, there are still far more supporters of the traditional system of higher education. Even the majority of distance students (43\%) would prefer real-life communication, traditional attendance of lectures, seminars, and office hours. Possibility to receive tasks and instructions, as well as progress tutorials via e-mail satisfies only $11 \%$ of the supporters of the distance education model. Preparation for lectures with the help of the Internet satisfies around $10 \%$ of the respondents in the group of distance education and $34 \%$ of full-time students. The most 
undesired form of learning by supporters of distance education model is video materials and slide lectures. Only $8 \%$ of the respondents would be willing to prepare for lectures with the help of the above-mentioned materials (Table 2).

Table 2

Methods of Preparation for Lectures by Students of the Distance Education Model (\% of the respondent number in the group)

\begin{tabular}{lccccc}
\hline & Latvia & Serbia & Belarus & Lithuania & Poland \\
\hline To attend a lecture, to read a textbook & 30 & 28 & 24 & 25 & 27 \\
\hline To meet lecturers at their office hours & 43 & 49 & 39 & 45 & 41 \\
\hline To prepare for lectures using the Internet & 11 & 13 & 11 & 9 & 10 \\
\hline $\begin{array}{l}\text { To watch video materials, recordings of lectures } \\
\text { or slide lectures }\end{array}$ & 5 & 6 & 11 & 9 & 10 \\
\hline $\begin{array}{l}\text { To receive information electronically (via } \\
\text { e-mail, computer program) }\end{array}$ & 11 & 4 & 15 & 12 & 12 \\
\hline
\end{tabular}

$14 \%$ of full-time students-respondents are ready to use video materials or slide lectures for preparation (Table 3).

Table 3

Methods of Preparation for Lectures by Full-time Students (\% of the respondent number in the group)

\begin{tabular}{lccccc}
\hline & Latvia & Serbia & Belarus & Lithuania & Poland \\
\hline To read a textbook in a library or at home & 55 & 55 & 51 & 51 & 47 \\
\hline To prepare for lectures using the Internet & 34 & 35 & 31 & 37 & 35 \\
\hline $\begin{array}{l}\text { To watch video materials, recordings of lectures } \\
\text { or slide lectures }\end{array}$ & 11 & 10 & 18 & 12 & 18 \\
\hline
\end{tabular}

The following conclusions can be drawn from the data listed above. Firstly, students who prefer the distance education form choose it not because of the form of the received materials but due to another reason. Secondly, students do not use information technology tools for acquisition of study information; they still prefer traditional forms of real-life communication with the lecturer. It is fair to assume that the preference of this form is a result of the education at school, based only on communication between the teacher and the student.

Moreover, there is evidence that full-time students are willing to have their education supplemented with up-to-date teaching and learning methods, using information technologies.

One of the advantages of the distance education model is the individualisation of the learning process. It means that each student may have his own lecture plan, based on variation between content and learning pace (Kop, 2011). With reference to it, there is a necessity to mention that an individual lecture plan initially includes core curriculum with respect to the established state education standard. Student has the right to include more courses in the individual plan of mandatory studies. The choice of extra lectures is offered from the list of elective (specialised) and optional (additional) study courses included in a particular education program (Regulations of the Cabinet of Ministers No. 240 "The Law on Higher Education Establishments"). 
Acquisition time of core courses may also vary. It means that if there is vocational secondary education available in the appropriate field or higher vocational education at different levels, the student has the right to a shortened higher education program. The reduction of the length of educational program is possible due to the knowledge, skills and experience gained by the student in prior learning process.

If the student of distance education cannot handle the study program within the set time-limit, there is a possibility to switch to a relatively slower learning pace.

From the point of view of study program developers, it is convenient for those students who want to acquire higher education on the basis of an individual plan. During the research, it has been determined that students from Serbia want to have an individual learning schedule; on the contrary, students from Belarus are not highly tempted by such an opportunity (Table 4).

Table 4

Preference for Distance Education Model over Traditional Education Model in Different European Countries (\% of the respondent number in the group)

\begin{tabular}{lcccccc}
\hline & Latvia & Serbia & Belarus & Lithuania & Poland \\
\hline Possibility to study according to an individual plan & 11 & 24 & 7 & 18 & 14 \\
\hline $\begin{array}{l}\text { Possibility to study independently, using } \\
\text { electronic resources }\end{array}$ & 7 & 6 & 9 & 7 & 14 \\
\hline Possibility to combine work and studies & 39 & 20 & 31 & 22 & 22 \\
\hline No obligation for daily lecture attendance & 25 & 19 & 24 & 17 & 23 \\
\hline Opportunity to start studies anytime & 9 & 25 & 14 & 31 & 25 \\
\hline Lower education fee & 9 & 6 & 15 & 5 & 2 \\
\hline
\end{tabular}

A key feature of distance education in comparison with the traditional model is the development of student's personal competencies and continuous self-study that are the tendencies of modern education. "The main aim of distance education is the arrangement of conditions for formation of independent cognitive activity during the study in developed academic environment, based on computer and telecommunication technologies" (Clark, 2002; Rovai, 2008). Nevertheless, the results of the survey have revealed a different situation in reality. Not all the students of distance education are determined to count on themselves, for example, in electronic exams and tests. It has been proven that only around half of students, on average $53 \%$, rely on self-decisions when implementing tasks. $27 \%$ of respondents rely on the assistance of cheat notes and $20 \%$ count on "sheer luck", using a little effort at exams and tests (Table 5). The most responsible students, according to the survey, are in Serbia and Lithuania.

Table 5

Students' Reliance on Success when Preparing for Electronic Exams and Tests (\% of the respondent number in the group)

\begin{tabular}{lcccccc}
\hline & Latvia & Serbia & Belarus & Lithuania & Poland \\
\hline $\begin{array}{l}\text { Hope that you will be lucky and do not study } \\
\text { for the exam }\end{array}$ & 19 & 22 & 27 & 16 & 16 \\
\hline $\begin{array}{l}\text { Use of "crib notes" or other illicit aid during the } \\
\text { examination process }\end{array}$ & 39 & 20 & 22 & 25 & 29 \\
$\begin{array}{l}\text { Use of personal knowledge and skills, being } \\
\text { prepared for the exam }\end{array}$ & 42 & 58 & 51 & 59 & 55 \\
\hline
\end{tabular}


Thus, it is necessary to emphasise that in the organization of distance learning process an important role is played by self-control: the students must rely on themselves in the majority of study courses. The results of the research have shown that $51 \%$ of the respondents try to use self-control. Unfortunately, they do not always succeed. Psychological problems that cannot be overcome by the student often arise, i.e., one needs an extra incentive from the "outside" expressed in the form of instruction or "punishment". There are also students ( $15 \%$ ) who do not even try to control themselves and follow a lesson plan, learn lecture material or do learning activities until the examination period. $14 \%$ of students wait until nearer the deadline (for example, two weeks remain) and only then start to prepare for the expected control. Only $20 \%$ of the respondents actually use self-control in the learning process systematically, by implementing different study tasks. It is hard to escape the conclusion that the education model based on mandatory consistency, independence and self-control, which are the main features of distance education, at this point is not sufficiently demanded by students.

The core disadvantages of the distance education model mentioned by the students are insufficiency of face-to-face communication with the lecturer and lack of practical studies (Table 6).

Table 6

Core Disadvantages of the Distance Education Model (\% of the respondent number in the group)

\begin{tabular}{lcccccc}
\hline & Latvia & Serbia & Belarus & Lithuania & Poland \\
\hline Lack of face-to-face communication with lecturers & 20 & 34 & 22 & 41 & 32 \\
\hline $\begin{array}{l}\text { The necessity of motivation and self-control } \\
\text { during the study process }\end{array}$ & 41 & 29 & 49 & 37 & 49 \\
\hline $\begin{array}{l}\text { Lack of practical exercises in order to use } \\
\text { theoretical knowledge }\end{array}$ & 39 & 37 & 29 & 22 & 19 \\
\hline
\end{tabular}

The system of test (multiple choice quiz) used for the assessment of student knowledge has received a lot of support in both traditional and distance education models. Requirements used in the assessment reveal several quality indicators: efficiency, reliability, usefulness, and economy. Within the distance technology, the quality monitoring system of knowledge acquisition in electronic testing is more popular. This distance education technology includes efficient lecture testing, individual computer training course, and module controlled assessment according to the results of specific subjects. Despite all advantages and disadvantages described in scientific literature (Gardiner, Corbitt, \& Adams, 2010; Ward, Peters, \& Shelley, 2010), this form of knowledge assessment is popular among the students, i.e., $52 \%$ of the respondents studying at traditional or distance education program favour this type of knowledge evaluation (Table 7). In other words, the system of assessment takes stable and positive position among the students.

In spite of the fact that distance education provides minimum face-to-face communication with the lecturer, there are no doubts that the professional level of the lecturers remains one of the key features influencing the satisfaction of students with the studies and the overall quality of specialist training. In relation to the research objective, Table 8 demonstrates results of students' attitude towards the cooperation with the lecturers in the study process and the quality of learning materials developed for the needs of distance education students. 
Table 7

Students' Preference of the Choice of Evaluation (\% of the respondent number in the group)

\begin{tabular}{lcccccc}
\hline & Latvia & Serbia & Belarus & Lithuania & Poland \\
\hline Passing a test or an exam in oral form & 14 & 34 & 9 & 18 & 11 \\
\hline $\begin{array}{l}\text { Passing a written test or an exam by selecting } \\
\text { an examination paper }\end{array}$ & 38 & 34 & 34 & 20 & 35 \\
\hline $\begin{array}{l}\text { Passing a written test or an exam in the form } \\
\text { of multiple choice quiz }\end{array}$ & 48 & 32 & 57 & 62 & 54 \\
\hline
\end{tabular}

Table 8

The Quality of the Learning Material and Cooperation with the Lecturers (\% of the respondent number in the group)

\begin{tabular}{lcccccccc}
\hline & \multicolumn{3}{c}{ Quality of the learning material } & \multicolumn{2}{c}{ Cooperation with the lecturers } \\
\hline & Excellent & Good & Satisfactory & Unsatisfactory & Good & Unsatisfactory & Other \\
\hline Belarus & 28 & 57 & 13 & 2 & 92 & 2 & 6 \\
\hline Latvia & 11 & 62 & 16 & 11 & 65 & 29 & 6 \\
\hline Serbia & 9 & 59 & 9 & 23 & 85 & 15 & 0 \\
\hline Poland & 19 & 69 & 8 & 4 & 76 & 20 & 4 \\
\hline Lithuania & 23 & 64 & 4 & 9 & 81 & 11 & 8 \\
\hline
\end{tabular}

The results of the research have revealed that $80 \%$ of the students evaluate the learning material as "good" and "excellent". Cooperation with the lecturers in the study process is evaluated as unsatisfactory only by $15 \%$ of the respondents. The highest quality of learning material is indicated by the respondents from Poland, but the highest level of cooperation between the lecturers and the students is stated to be in Belarus.

\section{Discussion}

The growth of the Internet and other technologies has resulted in the increase of online teaching and learning resources used in the routine practices of universities. At the same time, it has given distance education a new appeal. Distance learning is an increasingly popular education method being used by institutions in various countries to provide opportunities and meet the needs of a growing and increasingly diverse student population (Rumble \& Latchem, 2004).

Distance learning has a number of potential benefits, not least of which is the ability to overcome the temporal and spatial restrictions of traditional educational settings (Bates, 2005). Most students agree that e-learning could serve as a supplement for lectures and seminars. However, many students disagree with the statement that e-learning could replace traditional ways of teaching. The intensity of computer use and previous experience has the greatest effect on students' attitudes towards e-learning. The explanation for this could be general discomfort with the technology that makes students who lack experience with ICT express themselves cautiously about its use in education (Middendorff, 2002).

The present research has outlined the four main issues that are crucial for distance education students. 
1) Adaptability

Switching from a traditional classroom to a computer-based training in a virtual classroom makes the learning experience entirely different for students. Their resistance to a change does not allow them to adapt to the online learning environment and the methods of computer-based education. Students with a "traditional" mind-set find it difficult to adapt. Understanding the benefits of e-learning and even discussing them with their fellow students may change this mind-set and better prepare students for online classes.

2) Technical capabilities

Many students are not provided with the strong internet connection that online courses require and their distance learning experience becomes problematic. The only solution to this problem is being aware of technological support they will need for a certain course before enrolling in it, as well as properly equipping themselves for the successful completion of a particular course.

3) Computer literacy

Technological proficiency is a must for online courses, as it enables students to manage their assignments and courseware. While a majority of students possess sufficient computer skills and acknowledge the advantages of multimedia learning material, a small number of students still lack basic computer skills. Basic courses in computer literacy enhance students' knowledge in the field; having a fundamental knowledge of computer hardware would help them participate in online classes without interruptions and hindrances.

4) Self-control and motivation

Self-control and motivation are essential requirements of distance learning; however, many students lack them. Students need to find the motivation to follow the new educational trends and also properly equip themselves for future challenges in their education and career. A variety of factors have been identified as crucial to the success of online courses (McIsaac \& Gunawardena, 1996). Motivation is one such factor (Bekele, 2010). Just as motivation is a key factor in learning and achievement in face-to-face educational contexts (Brophy, 2010), so it is in online learning environments (Jones \& Issroff, 2007). Poor motivation has been identified as a decisive factor in contributing to the high dropout rates from online courses (Muilenburg \& Berge, 2005).

Only positive attitudes towards distance learning will help students overcome the challenges; students need to understand that it is necessary in order to reap the distance learning benefits in the future.

\section{Conclusion}

To conclude, the present research has revealed that traditional organisation of education based on real-life communication between the lecturer and the student currently dominates over the students' educational needs. The distance education model at the current stage of development remains not fully demanded. According to the research results, reasons for this tendency are the following: firstly, the level of required use of information and communication technologies in education is notably higher than existing knowledge, skills and experience of the students; secondly, such education stages as preschool and school do not offer alternatives for classes with teacher; therefore, the students prefer the classical methods of education. Some complexity of adaptation to 
modern educational methods has also been observed, as the latter ones are initially included in the independent acquisition of learning material. Therefore, the distance education model at Latvian higher education institutions does not still include all the possibilities that undeniably could substantially increase the efficiency of learning at higher education institutions.

Despite the need for improvement, the future of distance learning seems bright. Increasing numbers of students enrolling in distance learning classes underscore the need for comprehensive and thoughtful evolution of distance education if it is to become the educational model of the future (Harnar, et al., 2000).

\section{Acknowledgements}

The research has been supported by the National Research Program 5.2 "Economic Transformation, Smart Growth, Governance and Legal Framework for the State and Society for Sustainable Development - A New Approach to the Creation of a Sustainable Learning Community”, Project EKOSOC_LV.

\section{References}

Bates, A. W. (2005). Technology, e-learning and distance education (2nd ed.). New York: RoutledgeFalmer.

Bekele, T. A. (2010). Motivation and satisfaction in internet-supported learning environments: A review. Educational Technology \& Society, 13(2), 116-127.

Clark, R. (2002). Six principles of effective e-Learning: What works and why. The e-Learning Developer's Journal, 1-10.

Brophy, J. (2010). Motivating students to learn (3rd ed.). New York: Routledge.

European Computer Driving Licence Foundation. (2014). Retrieved 2 September 2014 from http://www.ecdl.org/programmes/ecdl_icdl

Gardiner, L.R., Corbitt, G., \& Adams, S.J. (2010). Program assessment: Getting to a practical how-to model. Journal of Education for Business, 85, 125-147.

Garrison, R. (2000). Theoretical challenges for distance education in the 21st century: A shift from structural to transactional issues. The International Review of Research in Open and Distance Learning, 1. Retrieved 23 September 2015 from http://irrodl.org/index.php/irrodl/article/view/2/333

Harnar, M.A., Brown, S.W., \& Mayall, H. J. (2000). Measuring the effect of distance education on the learning experience: Teaching accounting via PictureTel. International Journal of Instructional Media, 27(1), 37-49.

Holmberg, B. (2008). The Evolution, Principles and Practices of Distance Education. Oldenburg BIS-Verlag der Carl von Ossietzky University Oldenburg.

Jones, A., \& Issroff, K. (2007). Learning technologies: Affective and social issues. In G. Conole \& M. Oliver (Eds.), Contemporary perspectives in e-learning research: Themes, methods and impact on practice (pp. 190-202). London: Routledge.

Kapenieks, J., \& Salite, I. (2012). Action research for creating knowledge in an e-learning environment. Journal of Teacher Education for Sustainability, 14(2), 111-129.

Khan, B.H., \& Ally, M. (2015). International Handbook of E-learning, Volume 1: Theoretical Perspectives and Research. London, New York: Routledge, Taylor \& Francis Group. 
Kop, R. (2011). The challenges to connectivist learning on open online networks: Learning experiences during a massive open online course / R. Kop // International Review of Research in Open and Distance Learning, 12(3).

McIsaac, M. S., \& Gunawardena, C. N. (1996). Distance education. In D. H. Jonassen (Ed.), Handbook of research for educational communications and technology: A project of the association for educational communications and technology (pp. 403437). New York: Macmillan Library Reference.

Middendorff, E. (2002). Computer use and new media in higher education. Results from the 16th social survey of the German Students Association conducted by the HIS Higher Education-Information-System Bonn. (Germany): Bundesministerium für Bildung und Forschung.

Muilenburg, L. Y., \& Berge, Z. L. (2005). Student barriers to online learning: A factor analytic study. Distance Education, 26(1), 29-48. doi: 10.1080/01587910500081269

Perraton, H. (2007). Open and distance learning in the developing world (2nd ed.). London: Routledge.

Robinson, B., \& Latchem, C. (2003). Teacher education: Challenge and change. In B. Robinson \& C. Latchem (Eds.), Teacher education through open and distance learning (pp. 1-27). London: Routledge Falmer.

Rovai, A. (2008). Distance Learning in Higher Education / A. Rovai, M. Ponton, J. Baker. New York: Columbia University Press.

The Cabinet of Ministers of the Republic of Latvia. (2014). Regulations on the State Standard of the Academic Education. Regulations No. 240 (13 May 2014).

The Law on Higher Education Establishments (Latvia). 1995 (amendments on 14 July 2011).

UNESCO. (2002). Open and Distance Learning: Trends, Policy and Strategy Consideration. Division of Higher Education, UNESCO, ED.2003/WS/50.

Ward, M. E., Peters, G., \& Shelley, K. (2010). Student and faculty perceptions of the quality of online learning experiences. The International Review of Research in Open and Distance Learning, 11(3), 55-77.

Correspondence concerning this paper should be addressed to Dr.sc.admin., Associate Professor Daina Vasilevska, Liepaja University, Lielā iela 14, Liepāja, LV-3401, Latvija. Email: daina.vasilevska@gmail.com 